\title{
GAMBARAN PERILAKU PICKY EATER DAN FAKTOR YANG MELATAR BELAKANGINYA PADA ANAK USIA 2-4 TAHUN DI RW XII KELOMPOK BERMAIN DAN RAUDHATUL ATHFAL ALAMTERPADU UWAIS AL QORNI SURAKARTA
}

\author{
Ika Budi Wijayanti ${ }^{1 *}$, Hutari Puji Astuti ${ }^{1}$ dan Danik Riawati ${ }^{2}$ \\ ${ }^{1}$ Prodi D3 Kebidanan, STIKes Kusuma Husada Surakarta \\ ${ }^{3}$ Prodi DIII Teknologi Bank Darah, Akademi Teknologi Bank Darah Surakarta \\ ${ }^{1}$ Jl. Jaya Wijaya no 11 Kadipiro Mojosongo solo \\ Telp./Fax. (0271) (0271857742) \\ Email : ikawijayanti060580@gmail.com, uthe_dwi@yahoo.co.id \\ ${ }^{2}$ Jl. Sumbing Raya Mojosongo, Jebres, Kota Surakarta \\ Telp./Fax. (0271) 8591185 \\ Email : riawatidanik81@gmail.com
}

\begin{tabular}{l} 
Article Info \\
\hline Article history: \\
Received January $2^{\text {th }}, 2020$ \\
Revised February $5^{\text {th }}, 2020$ \\
Accepted March $30^{\text {th }}, 2020$ \\
\hline
\end{tabular}

Keyword:

Children aged 2-4 years; Picky Eater.

\begin{abstract}
Background: Researcher knows the phenomenon experienced by children picky eater.This is proven results early screening conducted by researcher, revealed the children had as many as $82 \%$ picky eater, but behavior picky eater experienced by children classified as slight extent because not until affect growth.As many as $45 \%$ mother feel it as a problem

Research Methods : Still a little research on picky eater done in Indonesia, but is still very picky eater of information about needs to develop .In general the knowledge to know the reason that mother about picky eater such behavior in children age a preschool program in kindergarden Uwais Qorni Surakarta.
\end{abstract}

Research Result : The result is a low variation in the types of food that children consume daily. In general, children eat the same type of food a day and the type of food does not differ much every day. The low variety of child food types is caused by the mother cooking only once for one day, on the grounds that the mother does not have enough time. In fact, the majority of informants in this study were housewives who spent a lot of time at home.

Conclusion : The behavior of the picky eater is a common dietary phase for children. The common picky eater behaviour found in this research is limited food variation, so that the child looks to choose the type of food they are being smoked.

Copyright $@$ Jurnal Gizi Prima All rights reserved.

\section{PENDAHULUAN}

Anak adalah aset bangsa dan generasi penerus cita-cita perjuangan bangsa yang akan menentukan masa depan bangsa dan negara kita. Oleh karena itu perhatian dan harapan yang besar perlu diberikan kepada anak (Infodatin, 2014). Sikap terbaik yang dapat diambil orangtua dalam menghadapi penolakan makan oleh anak adalah dengan mengabaikannya kemudian mencoba lagi lain waktu di saat yang tepat (Garrow dan James, 1996). Berdasarkan hasil observasi awal, peneliti menangkap besarnya fenomena picky eater yang dialami anak. Hal ini terbukti dari hasil skrining awal yang dilakukan oleh peneliti, menunjukkan hasil sebanyak $82 \%$ anak mengalami picky eater, namun perilaku picky eater yang dialami oleh anak tergolong tingkat ringan karena tidak sampai memengaruhi pertumbuhan. Hal ini terlihat dari 
status gizi abak yang masih tergolong baik. Sebanyak $45 \%$ ibu merasakannya sebagai sebuah masalah. Kebanyakan ibu, yang umumnya berusia muda, merasa bingung dalam menghadapi perilaku ini dan mengeluhkan kabiasaan picky anaknya. Tidak banyak dari mereka yang benar-benar memahami faktor yang melatar belakangi perilaku ini. Akhirnya, mereka menyimpulkannya masing-masing dan mengambil langkah yang berbeda-beda, yang mereka anggap tepat, untuk menghadapi perilaku makan anaknya. Selain itu, masih sedikit sekali penelitian mengenai picky eater yang dilakukan di Indonesia, padahal pengetahuan mengenai picky eater masih sangat perlu dikembangkan. Hal inilah yang menarik minat peneliti untuk meneliti lebih lanjut mengenai Gambaran Perilaku Picky Eater Dan Faktor Yang Melatar Belakanginya Pada Anak Usia 2-4 Tahun Di RW XII Kelompok Bermain Dan Raudhatul Athfal AlamTerpadu Uwais Al Qorni Surakarta

\section{METODE PENELITIAN}

Metode penelitian kualitatif. Metode ini dipilih karena sesuai dengan tujuan peneliti, yaitu untuk memahami fenomena picky eater yang terjadi. Selain itu, juga bertujuan untuk menggali faktor-faktor yang melatar belakangi perilaku picky eater pada anak usia prasekolah di KB dan RA Alam Terpadu Uwais Al Qorni Surakarta. Sebelum melaksanakan penelitian, dilakukan beberapa persiapan, agar penelitian dapat berjalan lancar. Persiapan ini meliputi persiapan administrasi dan perijinan, serta persiapan teknis penelitian. Sebelum memulai pengumpulan data, peneliti melakukan skrining sederhana untuk mendapatkan data anak yang diasumsikan sebagai picky eater oleh orangtuanya. Data dikumpulkan dari beberapa sumber dengan menggunakan beberapa metode. Hal ini dilakukan untuk menjaga validitas dan reliabilitas data. Triangulasi (cross check) akan dilakukan untuk memenuhi informasi yang dibutuhkan. Triangulasi akan dilakukan hingga data jenuh, yaitu ketika tidak ada lagi informasi baru yang didapatkan dari responden (Putra, 2011). Data akan dikumpulkan langsung oleh peneliti melalui wawancara mendalam terhadap guru dan orangtua serta observasi anak. Skrining ini dilakukan dengan kuesioner peneliti dibantu oleh guru pengajar Kelompok Bermain Dan Raudhatul Athfal Alam Terpadu Uwais Al Qorni Surakarta untuk menjelaskannya kepada para murid. Kemudian, anak dikategorikan sebagai picky eater jika memenuhi minimal satu dari empat kriteria yang terdapat dalam kuesioner.

\section{Triangulasi Sumber \\ Guru}

Guru yang diwawancarai dalam pengambilan data adalah seorang guru penanggung jawab mata ajar. Dari guru, peneliti mengharapkan informasi mengenai perilaku makan anak selama di sekolah, bagaimana kebiasaan bekal makanan anak, serta bagaimana perilaku jajannya. Selain itu, guru juga ditanyai bagaimana proses belajar di kelas. Apakah selama di Kelompok Bermain Dan Raudhatul Athfal Alam Terpadu Uwais Al Qorni Surakarta guru juga menyampaikan pengetahuan dasar mengenai makanan sehat dan bagaimana siswa menanggapinya.

\section{Anak Balita}

Peneliti mengobservasi proses berjalannya kelas di Kelompok Bermain Dan Raudhatul Athfal Alam Terpadu Uwais Al Qorni Surakarta dalam beberapa hari. Lingkup observasi meliputi pelajaran yang diberikan selama di kelas, perilaku makan, jenis makanan bekal, dan perilaku jajan anak selama di sekolah. Selain itu, akan dilihat pula bagaimana interaksi antara ibu dan anak pada anak yang ditunggui maupun dijemput oleh orangtuanya.

\section{Orangtua}

Kepada orangtua siswa, dilakukan wawancara mendalam. Hal ini dilakukan untuk menggali informasi sebanyak-banyaknya kepada orangtua mengenai perilaku makan anaknya sehari-hari dan kesulitannya. kriteria yang digunakan dalam memilih orangtua sebagai informan adalah memiliki anak yang mengalami picky eater berdasarkan hasil skrining.

\section{HASIL PENELITIAN}

Terkait dengan metode penelitian yang digunakan, yaitu kualitatif, peneliti memilihnya karena sesuai dengan tujuan penelitian, yaitu ingin menggali dan memahami permasalahan yang ada secara mendalam. Keterbatasan yang ditemui dalam penelitian ini adalah triangulasi metode yang belum sepenuhnya terpenuhi. Beberapa variabel yang diteliti belum dapat di-cross check melalui wawancara mendalam dan observasi. Hal ini diantisipasi oleh peneliti dengan memperdalam wawancara yang dilakukan melalui berbagai pertanyaan yang dapat menggambarkan informasi yang diinginkan. Selain itu, ketiadaan definisi yang baku mengenai 
picky eater juga merupakan sebuah keterbatasan dalam penelitian ini. Dalam penelitian-penelitian sebelumnya mengenai picky eater, umumnya definisi mengenai picky eater hanya didasarkan pada persepsi individu masing-masing ibu terhadap perilaku makan anaknya. Belum ada definisi yang umum digunakan untuk menggambarkan dan membatasi perilaku apa saja yang tergolong picky eater. Untuk itu, peneliti menggunakan definisi picky eater menurut Carruth, et al (1998). Definisi ini digunakan karena penjabarannya yang lengkap dan spesifik dan sudah mencakup semua pendapat mengenai perilaku makan yang tergolong picky eater.

\section{Karakteristik Anak Picky Eater}

Perilaku picky eater pada anak, terutama usia prasekolah, merupakan hal yang umum dijumpai. Istilah picky eater sendiri bukan merupakan istilah yang umum digunakan di Indonesia, sehingga belum banyak orang yang memahami benar mengenai masalah ini. Umumnya, orangtua menyadari kesulitan makan yang dialami anaknya, namun belum memahami benar penyebab timbulnya kesulitan makan ini, dan cara untuk mengatasinya. Picky eater dalam penelitianini meliputi perilaku menolak makanan baru (neofobia), variasi jenis makanan yang terbatas, menolak sama sekali makanan yang tidk disukai, dan hanya ingin makan makanan yang disukai (Carruth, et al, 1998).

Dari hasil penelitian ini, diketahui bahwa mayoritas ibu mengakui anaknya memiliki masalah dengan perilaku makannya. Berdasarkan hasil skrining yang dilakukan di awal penelitian, didapatkan sebanyak $82 \%$ anak dikategorikan sebagai picky eater. Penelitian lain juga menunjukkan bahwa picky eater cukup banyak dialami pada anak usia prasekolah. Penelitian tersebut antara lain dilakukan oleh Carruth, et al pada tahun 2004, menunjukkan bahwa picky eater dialami oleh sebanyak 23\%-54\% anak perempuan dan 17\%-47\% anak laki-laki. Penelitian lain oleh Beautris, et al dalam Wright, et al pada tahun 2007 mendapati sebanyak 24\% responden di New Zealand menyatakan anaknya memiliki masalah sulit makan di usia 2 tahun dan 18\% diantaranya berlanjut hingga usia 4 tahun. Dikutip dari sumber yang sama, Wright, et al (2007), Richman, et al di Inggris menemukan $17 \%$ anak digambarkan orangtuanya memiliki nafsu makan yang rendah dan $12 \%$ lainnya mengalami picky eaters.

Hasil wawancara mendalam menunjukkan seluruh informan mengeluhkan anaknya memiliki masalah dengan perilaku makannya. Hasil wawancara ini diperkuat dengan hasil observasi selama beberapa hari yang menunjukkan perilaku makan anak di sekolah sedikit bermasalah, terutama dalam pemilihan jenis makanan. Selain itu, hasil wawancara dengan guru menunjukkan hasil yang sama, bahwa anak sedikit memiliki masalah dengan perilaku makannya. Namun, guru lebih menyoroti permasalahan makan ini dari sisi disiplin makan anak.

Selain itu, dari hasil wawancara mendalam, didapati anak-anak ini mulai mengalami kesulitan perilaku makan ketika mulai mengenal dan belajar makan makanan keluarga.Namun, adapula informan yang menyatakan problem sulit makan pada anaknya timbul sejak pemberian makanan padat. Jika dibandingkan dengan penelitian Benton (2004) dan Dovey (2008) yang dikutip dalam Ekstein, Laniado, dan Glick (2010), diketahui bahwa picky eater umumnya pertam muncul pada usia dua tahun, memuncak antara umur 2-6 tahun, dan semakin berkurang seiring bertambahnya usia. Penelitian Carruth, et al pada tahun 2004, menunjukkan bahwa prevalensi picky eater meningkat berdasarkan usia, antara 19\%-50\%, pada anak usia 424 bulan. Sedangkan menurut Greene tahun 2011, prevalensi picky eater meningkat antara $13 \%$ hingga $22 \%$ pada anak usia 2-11 tahun.

Berdasarkan hasil penelitian-penelitian di atas, dapat disimpulkan bahwa perilaku makan sulit, khususnya picky eater, merupakan hal yang jamak ditemui pada masa kanak-kanak, khususnya usia prasekolah. Beberapa faktor yang melatar belakangi timbulnya picky eater ini merupakan faktor internal, yang berasal dari dalam diri anak, antara lain penurunan laju pertumbuhan dan perkembangan psikologis anak. 


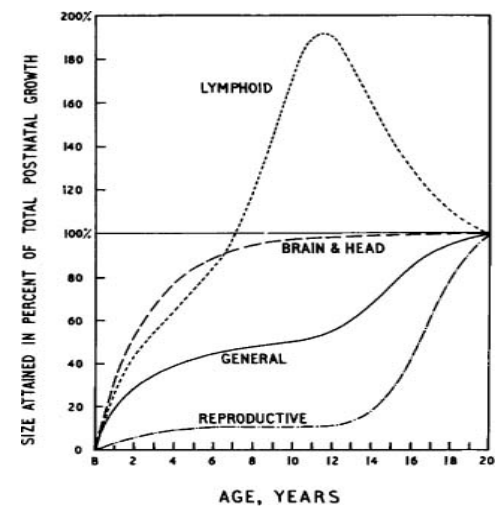

Gambar 1. Grafik pertumbuhan jaringan tubuh (growth of various body tissue)

Dari gambar 1. terlihat bahwa sepanjang hidupnya, manusia akan mengalami dua kali masa percepatan pertumbuhan (growth spurt), yaitu semasa di dalam kandungan hingga usia dua tahun dan saat memasuki masa pubertas. Dari gambar di atas, dapat dilihat bahwa setelah melewati usia dua tahun, laju pertumbuhan manusia mulai melandai. Hal ini berkaitan erat dengan penurunan nafsu makan anak, sehingga secara kuantitas, asupan makan anak cenderung menurun dan anak kerap dicap berperilaku picky eater. Selain itu, penurunan kebutuhan zat gizi pada anak juga menyebabkan ketertarikan anak terhadap makanan cenderung menurun (Wardlaw dan Hampl, 2007; E. Brown, 2011; Sutarjo, 2011)

Anak juga banyak mengalami perubahan perilaku sejak bayi hingga memasuki usia pra-sekolah. Menurut Greene (2011), anak cenderung suka memasukkan benda apapun yang disentuhnya ke dalam mulut ketika bayi. Hal ini merupakan salah satu cara penting bagi anak dalam mengeksplorasi dunia di sekitarnya. Namun, segera setelah mampu berjalan, anak menjadi jauh lebih pemilih akan benda-benda yang masuk ke dalam mulutnya. Mereka secara naluriah memiliki rasa curiga terhadap makanan yang baru dikenalnya. Hal ini dikarenakan anak memiliki indera pengecap (papilla) yang lebih sensitif jika dibandingkan dengan orang dewasa (Wardlaw dan Hampl, 2007).

\section{Variasi Makanan Anak}

Keragaman jenis makanan yang diasup anak menjadi faktor yang saling mempengaruhi dengan perilaku picky eater pada anak. Berdasarkan hasil wawancara mendalam didapatkan informasi bahwa umumnya, jenis makanan yang dikonsumsi anak sehari-hari sama sejak pagi hingga sore. Selain itu, ketika ibu sedang tidak memasak, maka ibu akan membeli makanan di warung. Dari hasil wawancara mendalam dengan guru di Raudhatul Athfal Alam Terpadu Uwais Al Qorni Surakarta juga didapatkan informasi bahwa ibu kerap membawakan bekal tertentu dengan jenis yang sama selama beberapa hari. Hal ini menunjukkan terbatasnya variasi makanan yang dikonsumsi anak sehari-hari. Beberapa informan juga merasa memiliki andil dalam perilaku piky eater anak.

“...Semisal sudah ketahuan mau makan ini, gak mau makan ini, ya udah. Kalo pas lagi gak mau makan, saya kasih makanan yang dia mau. Jadi saya suka mikir lagi, apa karena saya ga nyoba-nyobain makanan ke dia atau gimana..."

“...Kalo kata saya sih ini, mamanya males kali ya? Terlalu pengen buru- buru gitu, kalo kata saya sih. Harusnya telaten kan ininya, cobain...”

Mereka merasa perilaku picky eater muncul karena kegagalan pengenalan makanan ketika anak mulai belajar makan. Akibatnya, anak hanya mengenal sedikit jenis makanan dan menjadi pemilih. Padahal, menurut hasil penelitian Skinner et al (2002), yang diacu dalam Carruth et al (2004), pengenalan jenis makanan sejak dini pada anak dapat memengaruhi penerimaan makan mereka ketika sudah lebih besar.

\section{Perilaku Makan Anggota Keluarga Lain}

Dari hasil yang didapatkan dalam penelitian ini, diketahui bahwa mayoritas ibu, sebagai informan, tidak ada yang bermasalah dengan perilaku makannya. Namun, terdapat satu ibu yang mengaku tidak menyukai jenis makanan tertentu, yaitu ikan lele. Permasalahan perilaku makan muncul dari nggota 
keluarga lain, yaitu ayah, kakak dan adik. Permasalahan perilaku makan yang muncul adalah pemilih dan bermasalah dengan tekstur makanan.

Beberapa penelitian lain menunjukkan hasil yang kurang lebih serupa. Berdasarkan penelitian yang dilakukan oleh Priyanah, pada tahun 2008 di Klinik Picky Eater Jakarta, diketahui bahwa umumnya, anak yang mengalami picky eater juga memiliki anggota keluarga lain yang mengalami masalah dalam perilaku makannya. Dalam penelitian ini, anggota keluarga lain yang dinilai adalah ibu. Mayoritas anak yang mengalami picky eater memiliki ibu yang tidak menyukai buah.Penelitian lain yang dilakukan oleh Horodynski, pada tahun 2010 di Amerika Serikat, menunjukkan bahwa asupan buah dan sayur anak berhubungan erat dengan asupan buah dan sayur ibu. Hasil penelitian yang dilakukan oleh Galloway, Lee, dan Birch pada tahun 2003 menyatakan bahwa anak yang picky eater memiliki ibu dengan variasi asupan sayur yang rendah. Studi lain yang dilakukan Messina et al (2002), dalam sumber Cathey dan Gaylord (2004) menunjukkan bahwa sikap ibu terhadap gizi dan kebiasaan makan ibu akan memengaruhi pilihan makan anak. Semua penelitian ini menunjukkan kesamaan bahwa anak yang picky eater umumnya memiliki ibu dengan variasi asupan makan yang terbatas pula.

Hal ini sesuai dengan teori yang ada. Menurut Wardlaw dan Hampl (2004) masa-masa penting pembentukan kebiasaan makan yang sehat pada anak terjadi pada saat usia prasekolah. Untuk itu, anak membutuhkan contoh yang baik agar bisa membentuk kebiasaan makan yang baik. Anak terlahir tanpa memiliki pengetauan tentang diet yang baik bagi mereka. Oleh karena itu, anak membentuk kebiasaan makannya sendiri melalui pengalaman yang didapat dan dipelajarinya (Rasanen, et. al, 2001). Selain itu, anak dikenal sebagai peniru ulung. Mereka banyak menirukan lingkungan sekitarnya, termasuk meniru perilaku makan (Brown, 2011). Anak sebagai peniru, akan cenderung lebih menikmati makanan yang berariasi jika ia melihat orangtuanya juga dapat menikmati makanan yang bervariasi (Brown, 2011; Wardlaw dan Hampl, 2004).

\section{Interaksi Anak dan Orangtua}

Interaksi anak dan orangtua dapat diartikan sebagai hubungan timbal balik antara orangtua dan anak yang terjalin dengan intens. Orangtua berada di lingkungan yang terdekat dengan anak, yaitu keluarga.Oleh karena itu, orangtua idealnya memiliki porsi interaksi yang besar dengan anak, terutama ketika anak tersebut masih kecil. Interaksi orangtua dan anak yang baik akan mampu membentuk kepribadian yang baik dalam diri anak. Dari hasil wawancara mendalam terhadap para informan dalam penelitian ini didapatkan bahwa mayoritas informan berprofesi sebagai ibu rumah tangga.Sebagai ibu rumah tangga, informan banyak menghabiskan waktunya di rumah, sehingga banyak waktunya dihabiskan untuk berkegiatan dengan anak. Satu orang ibu ada yang bekerja sebagai perawat dengan dua shift kerja, sehingga informan tersebut hanya memiliki sedikit waktu di rumah. Namun, interaksi ibu dan anak tetap berjalan dengan baik.Ibu selalu berusaha memaksimalkan waktu yang dimilikinya selama di rumah untuk dihabiskan bersama anak.Selain itu, anak juga banyak menghabiskan waktu dengan ayahnya ketika tidak bersama dengan ibu. Interaksi yang terbangun pada waktu makan masih terbilang rendah. Hal ini terlihat dari jarangnya para informan melakukan kegiatan makan bersama dalam satu meja.

Hal ini sedikit berbeda dari hasil penelitian lain. Dengan interaksi yang postif antara orang tua dan anak, diharapkan anak dapat membentuk perilaku yang baik. Hubungan yang kuat anatara orangtua dan anak memiliki peran protektif terhadap perkembangan emosi dan sikap serta permasalahan kesehatan pada anak (Carlson, et al; Fonagy, et. al; Greenberg, et. al; dan Main diacu dalam Benoit, et. al, 2001). Hubungan keluarga yang baik, yaitu minim konflik, eratnya hubungan antar anggota keluarga, dan membiarkan anaknya menjadi mandiri, menjadi carayang lebih efektif dalam menangami permasalahan makan daripada dengan memberikan makanan kesukaan sebagai hadiah. Interaksi antara orangtua dan anak tidak hanya dibutuhkan dalam kegiatan bermain saja, namun juga diperlukan pada waktu makan. Perilaku makan dan berat badan anak juga berhubungan dengan interaksi orangtua dan anak dalam mendukung anaknya untuk makan (Klesges yang diacu dalam Oliveria, 2008).

Hal tersebut sesuai denga teori yang ada. Menurut Soetardjo (2011), lingkungan sosial emosional anak, meliputi waktu pendampingan saat makan, suasana positif di rumah, dan perilaku makan orangtua, berkaitan dengan kuantitas dan kualitas asupan makan anak.

Jadi dapat disimpulkan bahwa interaksi yang terjalin antara orangtua dan anak dalam penelitian ini belum cukup kuat untuk membangun perilaku makan yang baik pada anak.Hal ini mungkin disebabkan oleh 
kurangnya interaksi pada saat pendampingan waktu makan.Ini terbukti dari jarangnya semua informan makan bersama di dalam keluarganya.Umumnya, informan mendahulukan waktu makan anak, dengan menyuapinya terlebih dahulu, baru kemudian ibu bisa makan setelahnya. Padahal, akan lebih baik jika keluarga makan bersama dalam satu meja. Karena dengan demikian, dapat terbangun suasana kebersamaan diantara keluarga dan anak dapat mencontoh secara langsung bagaimana perilaku makan yang baik dan sesuai. Anak pada usia prasekolah umumnya sudah memiliki kemampuan motorik halus yang baik untuk dapat makan sendiri di atas meja makan, sehingga sangat memungkinkan untuk melakukan makan bersama.

\section{ASI Eksklusif}

ASI eksklusif merupakan makanan yang baik bagi bayi, bahkan merupakan makanan utama dan satu-satunya untuk bayi hingga usia enam bulan. Dari hasil penelitian ini, didapatkan informasi bahwa semua informan pernah memberikan ASI kepada anaknya semasa bayi. Namun, tidak ada satupun informan yang berhasil memberikan ASI secara eksklusif. Lama pemberian ASI oleh informan berbeda-beda, antara empat bulan hingga dua tahun. Selain durasi pemberian ASI yang tidak tepat, semua informan juga memberikan makanan maupun minuman selain ASI tidak sesuai dengan tahapan usianya.

Selain gagalnya pemberian ASI eksklusif, dari hasil wawancara mendalam juga didapatkan bahwa para informan memberikan makanan tambahan tidak sesuai dengan tahapan pertambahan usia anak. Umumnya, makanan yang menggagalkan pemberian ASI eksklusif pada para informan adalah susu formula. Selain itu, pemberian makanan padat oleh informan juga tidak sesuai usia anak. ada informan yang memberikannya terlalu cepat dan adapula yang memberikannya terlalu lambat.

Selain itu, pemberian ASI pada saat bayi juga penting dalam memperkenalkan rasa pada anak. Rasa ASI merupakan pengalaman awal yang penting bagi indera pengecap bayi (Brown, 2011). Menurut penelitian Garish dan Menella yang diacu dalam sumber yang sama dengan sebelumnya, rasa ASI dapat dipengaruhi oleh rasa makanan yang dikonsumsi ibu. Pajanan rasa yang beraneka dari ASI akan dapat membantu memperkenalkan rasa pada anak saat mulai mengonsumsi makanan padat.

Dapat disimpulkan bahwa gagalnya pemberian ASI eksklusif dan pemberian makanan padat yang tidak sesuai tahapan usia merupakan salah satu faktor yang melatar belakangi timbulnya picky eater pada anak. Hal ini dikarenakan anak gagal mengenal berbagai rasa dari ASI di awal kehidupannya.Kemudian, mereka mendapatkan pajanan rasa yang terlalu dini ketika masa ASI eksklusif. Umumnya, makanan yang dikenalkan ibu ketika bayi hanya satu jenis dalam waktu yang lama.Sehingga, di awal mengenal rasa, anak tidak banyak mengenal aneka rasa.Ini dapat mempersempit preferensi pilihn rasa bagi anak ketika besarnya.

\section{Pengetahuan Orangtua}

Pengetahuan, menurut Notoatmodjo (2010) merupakan hasil tahu yng didapat seseorang melalui penginderaan dengan melihat, meraba, merasa, mencium, maupun mendengar suatu objek. Pengetahuan kerap diidentikkan dengan pendidikan yang didapat. Karakteristik informan yang terlibat dalam penelitian ini berbeda-beda.Pendidikan terendah yang didapat informan adalah SMP, sedangkan pendidikan informan yang tertinggi adalah diploma 3. 2 orang informan berpendidikan diploma di bidang kesehatan.

Dari hasil wawancara mendalam juga diketahui bahwa sumber informasi kesehatan anak pada umumnya didapatkan ibu dari hasil bertanya pada teman, membaca, dan menonton televisi. Mayoritas informan belum bisa menyebutkan jawaban yang tepat ketika ditanyakan mengenai tahap pemberian makan anak dan konsep makanan yang baik untuk anak. Hal ini mengindikasikan bahwa informan belum dapat memilih informasi yang benar yang dapat digunakan untuk mengasuh anaknya. Menurut hasil penelitian Bramhagen, Axelsson, dan Hallstrom (2006) banyaknya sumber informasi yang memberikan informasi beragam bisa menjadi hal yang menguntungkan maupun menyulitkan.Ibu yang merasa diuntungkan dengan sumber informasi yangberagam akan cenderung lebih memilih informasi yang sesuai dengan keadaan dirinya.

Selain terhadap pilihan makanan anak, pengetahuan gizi yang dimiliki orangtua juga dapat secara langsung mempengaruhi perilaku makan anak dan kualitas dietnya. Berdasarkan hasil penelitian Räsänen et al, 2003 yang dimuat dalam Crites dan Aikman 2005, dapat mempengaruhi preferensi dan pemilihan jenis makanan seseorang walaupun dalam taraf yang rendah. Menurut hasil penelitian A. Tedstone, yang diacu dalam Rysdale (2008), pengetahuan gizi yang dimiliki orangtua memiliki hubungan positif dengan perilaku makan 
anak.Di samping itu, pengetahuan gizi yang dimiliki ibu juga menunjukkan hubungan positif terhadap kualitas diet anak (Conrad, et. al dalam horodynski, 2004).

Padahal, pengetahuan kerap menjadi dasar bagi seseorang dalam melakukan sesuatu.Orangtua, terutama ibu, yang merupakan pengasuh utama bagi anak dalam penelitian ini, memegang peranan penting dalam membangun kebiasaan makan yang baik bagi anak.menurut Soetardjo (2011), dalam bukunya Gizi Dalam Daur Kehidupan, menjelaskan bahwa pilihan makan anak akan sangat terpengaruh oleh pengetahuan gizi yang dimiliki orangtua dan pengasuh anak.

\section{Cara Menghadapi Picky Eater}

Perilaku makan anak dan sikap orangtua dalam menghadapinya merupakan konsep yang berhubungan dua arah (Ventura dan Birch, 2008). Sikap orangtua akan sangat berpengaruh dalam perilaku anak karena kemampuan orangtua dalam membentuk lingkungan di sekitar anak. Sebaliknya, sikap orangtua juga merupakan reaksi orangtua dalam menghadapi karateristik anak.

Perilaku makan yang berbeda-beda pada setiap anak dapat memancing reaksi yang berbeda-beda pula bagi ibu dalam menghadapinya.Dari hasil wawancara mendalam didapati bahwa umumnya ibu mengalah mengikuti keinginan anak. Ibu kerap memberikan makanan yang disukai anak agar anak mau makan. Adapula ibu yang mengaku sedikit memarahi anaknya jika anak menolak makan. Ibu juga kerap membujuk anak agar anak mau mencoba makanan yang baru dikenalnya.Umumnya, ibu juga tidak lagi memberikan jenis makanan baru yang ditolak anak pada kesempatan pertama.

Berdasarkan hasil penelitian Bramhagen (2006) di Swedia, terdapat dua karakter ibu dalam mengadapi perilaku makan anak.karakter ibu yang diharapkan ialah yang bersifat fleksibel, yaitu sensitif terhadap sinyal yang ditunjukkan anak, mendengarkan, dan merespon kemauannya. Merespon kemauan anak, bukan berarti mengikuti semua keinginan anak, melainkan mendengarkan anak hingga batasan yang wajar dan menanggapinya secara tepat. Menurut hasil penelitian Cathey dan Gaylord (2004) orangtua sangat tidak dianjurkan untuk mengikuti secara total kemauan anak dengan hanya menyediakan makanan yang mereka suka. Hal ini dapat membatasi kesempatan makanan anak untuk mengenal jenis makanan lain. Karakter yang tidak diharapkan adalah yang bersifat mengekang anak. pada karakter ini, ibu merasa bahwa dirinyalah yang paling berhak dan paling tahu mengenai asupan makan anak dan jadwal makannya. Mereka menemui kesulitan dalam menerjemahkan sinyal yang diberikan anak.

Jika dihadapi dengan salah, anak akan gagal membentuk kebiasaan makan yang baik. Pengalaman negatif, yang didapatkan anak yang berkaitan dengan makanan, akan berakibat pada penolakan makanan (Holden dan Mac Donald,2000). Bukannya perbaikan perilaku makan, anak justru akan semakin mengalami kesulitan dengan perilaku makannya. Penelitian lain yang dilakukan oleh Piazza, et al (2003), yang dikutip dalam Pizza et al (2004), diketahui bahwa ibu yang menghadapi perilaku makan dengan salah (mengalihkan perhatian, membujuk dengan berlebih, menyediakan makanan maupun mainan kesukaan anak) justru memperburuk perilaku makan anak pada $67 \%$ responden penelitiannya.

Selain dengan sikap yang ditunjukkan, penanganan picky eater juga ditunjukkan dengan melakukan suatu aksi. Mayoritas informan dalam penelitian ini mengaku memberikan tambahan asupan dengan maksud mencukupi kebutuhan anak. Informan yang memberikan suplemen vitamin mengaku memberikan vitamin tersebut karena khawatir asupan yang didapat dari makanan tidak mencukupi kebutuhannya. Selain itu, pemberian multivitamin penambah nafsu makan dimaksudkan agar anak meningkat nafsu makannya dan semakin mudah dalam menerima aneka jenis makanan. Adapula informan yang memberikan madu pada anaknya dengan tujuan sebagai penunjang imun tubuh anak. Informan lain memberikan obat cacing kepada anaknya karena khawatir anaknya sakit cacingan. Informan merasa demikian karena anak sulit makan dan tubuhnya terlihat kurus.

Padahal, berdasarkan penelitian yang dilakukan oleh Briefel, et al di Amerika Serikat pada tahun 2006, diketahui bahwa tidak ada perbedaan yang signifikan asupan yang signifikan antara anak yang mengonsumsi suplemen dan anak yang tidak mengonsumsi suplemen. 


\section{KESIMPULAN}

Perilaku picky eater merupakan sebuah fase perilaku makan yang umum ditemui pada anak. Perilaku picky eater yang umum ditemui dalam penelitian ini adalah variasi makanan yang terbatas, sehingga anak terlihat memilih jenis makanan yang diasupnya.

Faktor yang melatar belakangi munculnya picky eater pada anak, dalam penelitian ini, antara lain rendahnya variasi jenis makanan anak, perilaku makan anggota keluarga lain, rendahnya interaksi orangtua dan anak pada waktu makan, ASI eksklusif, pengetahuan orangtua, dan cara orangtua dalam menangani picky eater.

Dalam penelitian ini, terlihat rendahnya variasi jenis makanan yang diasup anak sehari-hari. Pada umumnya, anak mengonsumsi jenis makanan yang sama dalam sehari dan jenis makanan tidak banyak berbeda setiap harinya. Rendahnya variasi jenis makanan anak disebabkan ibu memasak makanan hanya sekali untuk satu hari, dengan alasan ibu tidak memiliki cukup waktu. Padahal, mayoritas informan dalam penelitian ini merupakan ibu rumah tangga yang banyak menghabiskan waktu di rumah.

Perilaku makan anggota keluarga lain, dalam penelitian ini, juga turut melatar belakangi timbulnya picky eater pada anak. Sebagian anak dalam penelitian ini memiliki anggota keluarga lain yang juga memiliki perilaku makan pemilih, baik ayah, maupun ibunya.

Interaksi yang terbangun antara anak dan orangtua pada waktu makan dinilai masih kurang terjalin, sehingga menjadi salah satu faktor yang melatar belakangi munculnya picky eater pada anak. kebanyakan keluarga informan dalam penelitian ini jarang melakukan makan bersama dalam satu meja. Umumnya,mereka mendahulukan waktu makan anak, dengan alasan anak masih harusdisuapi. Selain itu, alasan lain rendahnya interaksi yang terjalin pada waktu makan disebabkan sulitnya mencari waktu untuk mengumpulkan semua anggota keluarga secara utuh karena jadwal yang dimiliki berbeda-beda.

Dalam hasil penelitian ini, ditemui bahwa kegagalan pemberian ASI eksklusif juga turut melatar belakangi timbulnya picky eater pada anak. umumnya faktor yang menyebabkan pemberian ASI eksklusif adalah karena pemberian susu formula. Selain itu, ibu juga memberikan makanan padat tidak sesuai dengan tahapan usia yang seharusnya.

Sumber pengetahuan ibu dalam penelitian ini sudah beragam. Banyak sumber yang digunakan ibu dalam mendapatkan pengetahuan mengenai anak. Namun, terlihat pengetahuan ibu menganai anak masih banyak yang kurang tepat. Hal ini mungkin disebabkan karena ibu belum dapat memilah sumber informasi yang baik dan bisa dipercaya. Cara ibu dalam menghadapi perilaku picky eater juga merupakan faktor yang melatar belakangi munculnya picky eater pada anak. Ibu memiliki cara yang berbeda dalam menghadapi perilaku makan anaknya, antara lain dengan mengalah mengikuti kemauan anak, memberikan makanan yang disukai agar anak mau makan, membujuk, dan adapula yang memarahi anaknya. Umumnya, ibu juga tidak lagi mengulangi pemberian makanan yang sudah ditolak oleh anak.

\section{SARAN}

Diharapkan orangtua meingkatkan pengetahuan tentang gizi dan memberikan variasi jenis makanan dan memperhatikan perilaku makan anggota keluarga lain, serta meningkatkan interaksi antra orangtua dan anak pada waktu makan.

\section{DAFTAR PUSTAKA}

Benoit D, et. al. (2001). Atypical Maternal Behavior toward Feeding-DisorderedInfants Before and After Intervention. Infant Mental Health Journal,22(6), 611-626.

Bramhagen AC, Axelsson I, Hallström I. (2006). Mother's Experiences ofFeeding Situations-An Interview Study. Journal of Clinical Nursing, 15,29-34.

Brown, Judith E. (2005). Toddler and Preschooler Nutrition in Nutrition Through the Life Cycle 2nd edition.

Carruth BR, et. al. (1998). The Phenomenon of "Picky Eater": A Behavioral Marker in Eating Patterns of Toddlers. Journal of the American College of Nutrition, 17(2), 180-186. 
Carruth BR, Skinner JD. (2000). Revisiting the Picky Eater Phenomenon: Neophobic Behaviors of Young Children. Journal of the American College of Nutrition, 19(6), 771-780.

Carruth BR, Ziegler PJ, Gordon A, Barr SI. (2004). Prevalence of Picky Eaters among Infamts and Toddlers and Their Caregiver's Decisions about Offering a New Food. Journal of the American Dietetic Association, 104: S57-S64.

Crites Jr. SL, Aikman SN. (2005). Impact of Nutrition Knowledge on FoodEvaluations. European Journal of Clinical Nutrition, 59. 1191-1200.

Dubois L, et. al. (2007). Problem Eating Behavior Related to Social Factors and Body Weight in Preschool Children: A Longitudinal Study. International Journal of Behavioral Nutrition and Physical Activity, 4:9.

Dubois L, Farmer AP, Girard M, Peterson K. (2007). Preschool Children's Eating Behaviors are Related to Dietary Adequacy and Body Weight. European Journal of Clinical Nutrition, 61, 846-855.

Ekstein S, Laniado D, Glick B. (2010). Does Picky Etaing Affect Wight-for- Length Measurements in Young Children. Clinical Pediatrics, 49(3) 217-220.

Garrow JS dan James WPT. (1996). Human Nutrition and Dietetics. London: Churchil Livingstone.

Holden C dan Mac Donald A. (2000). Nutrition and Child Health. London: Hartcourt Publisher, Ltd.

Horodynski MA, et. al. (2010). Low Income African American and Non-Hispanic White Mothers' Self Efficacy, "Picky Eater" Perception, and Toddler Fruit and Vegetable Consumption. Public Health Nursing, 27(5), pp 408-417.

Horodynski MAO, Hoerr S, Coleman G. (2004). Nutrition Education Aimed at Toddlers: A Pilot Program for Rural, Low-Income Families. Family and Community Health, 27(2), pp. 103-113.

Infodatin, (2014), Pusat data dan Informasi Kementerian Kesehatan RI

Liu YH, Stein MT. (2005). Feeding Behavior of Infants and Young Children and Its Impact on Child Psychosocial and Emotional Development. Encyclopedia on Early Childhood Development.

Luwina, Genta Sari. (2006). Pengaruh Stimulasi Gizi dan Kesehatan Terhadap Status Gizi dan Kesehatan Peserta Kelompok Bermain di Kota Bogor. Skripsi. Gizi Masyarakat dan Sumberdaya Keluarga. Fakultas Pertanian. Institut Pertanian Bogor, Bogor.

Marshall C dan Rossman GB. (2014). Designing Qualitative Research. Sixth Edition, CA: Sage.

Meirita. (2000). Hubungan Kuantitas dan Kualitas Waktu Ibu Untuk Pengasuhan dengan Status Gizi Anak Balita di Desa Rancamaya Kota Bogor. Skripsi. Gizi Masyarakat dan Sumberdaya Keluarga. Fakultas Pertanian. Institut Pertanian Bogor, Bogor.

Micali N. (2005). Childhood Risk Factors: Longitudinal Continuities and EatingDisorders.Journal of Mental Health, 14(6), 567-574.

Nicholls D. (2004). Eating Problems in Childhood and Adolescence. In Kevin Thompson (Ed), Handbook of Eating Disorder and Obesity (pp. 635-639). New Jersey: John Wiley\&Sons, Inc.

Oliveria SA dan Curtis E. (2008). Parent-Child Relationship in Nutrient Intake: the Framingham Children Study. The American Journal of Clinical Nutrition.

Piazza, Cathleen C. dan Carol-Hernandez, Tammy A. (2004). Assessment and Treatment of Pediatric Feeding Disorders. Encyclopedia on Early Childhood Development. 
Powers SW, et. al. (2006). Maternal Feeding Strategies, Child Eating Behaviors, and Child BMI in LowIncome African-American Preschoolers. Obesity,14(11).

Priyanah. (2008). Gambaran Karakteristik Anak Picky Eater yang Pernah Memeriksakan Diri di Klinik Picky Eater Jakarta Tahun 2008. Skripsi. FKM UI, Depok.

Pusat Kesehatan Kerja Depkes RI. (2008). Advokasi Sebagai Alat Perubahan. www.depkes.go.i

Putra, N. (2011). Penelitian Kualitatif: Proses dan Aplikasi. Jakarta: Indeks.

Räsänen M, et. al. (2001). Nutrition Knowledge and Food Intake of Seven-Year- Old Children in an Atherosclerosis Prevention Project with Onset in Infancy: the Impact of Child Targeted Nutrition Counselling Given to the Parents. European Journal of Clinical Nutrition, 55, 260-267.

Rysdale L, et. al. (2008). Evaluation of a Nutrition Education Component Nested in NutriSTEP Project. Canadian Journal of Dietetic Practice and Research, 69(1).

Saarilehto S, et. al. (2004). Growth, Energy Intake, and Meal Pattern in Five- Year-Old Children Considered as Poor Eaters. The Journal of Pediatrics,144, 363-7.

Tseng AG, Biagioli FE. (2009). Counseling on Early Childhood Concerns: Sleep Issues, Thumb Sucking, Picky Eating, and School Readiness. American Family Physician, 80(2), 139-142.

Ventura AK dan Birch LL. (2008). Does Parenting Affect Cildren's Eating and Weight Status?. International Journal of Behavioral Nutrition and Physical Activity, 5:15.

Wardlaw GM dan Hampl JS. (2007). Perspectives in Nutrition 7th ed. New York: Mc Graw Hill.

Wooldridge NH. (2011). Toddler and Preschooler Nutrtition. In Brown JE.Nutrition Through the Life Cycle 4th ed. California: Wadsworth CengageLearning.

Wright CM, Parkinson KN, Shipton D, Drewett RF. (2007). How do Toddler Eating Problems Relate to Their Eating Behavior, Food Preverences and Growth Pediatrics, 2014 